\title{
Implementation of Risk-Based Inspection (RBI) in Condensate Separator and Storage Vessel: A Case Study
}

\author{
Nurhadi Siswantoro ${ }^{1}$, Dwi Priyanta ${ }^{2}$, Jamal Ramadhan ${ }^{3}$, Muhammad Badrus Zaman ${ }^{4}$ \\ (Received: 21 August 2020 / Revised: 03 March 2021 / Accepted: 23 March 2021)
}

\begin{abstract}
It needs a method to prevent the failure of the pressure vessel. The Risk-Based Inspection (RBI) is a systematic approach to the inspection management method for equipment based on the level of risk. RBI is expected to provide sufficiently accurate recommendations to prevent equipment failures. In this research, the objects to be carried out are the $10 \mathrm{~V} 2102$ condensate separator and the $10 \mathrm{~V} 2103$ condensate storage vessel. According to RBI analysis, the risk category of the current RBI date is low risk for the condensate separator $10 \mathrm{~V} 2102$ and condensate storage vessel 10V2103. Meanwhile, the inspection date of Condensate Separator 10V2102 is 2 April 2026 and 11 February 2027 for Condensate Storage Vessel 10V2103 and selected inspection methods are Visual Testing, Ultrasonic Testing (UT), Radiography Test (RT), Eddy Current Test, and Magnetic Particle Inspection.
\end{abstract}

Keywords_-inspection, pressure vessel, risk, RBI.

\section{INTRODUCTION}

$\mathrm{T}_{\mathrm{h}}$ he pressure vessel is one of the important pieces of equipment in the oil and gas production process [1], [2]. In this research, the objects to be carried out are the 10V2102 condensate separator and the 10V2103 condensate storage vessel. Where the condensate separator is a vessel used to separate fluid and gas, the separated condensate fluid will collect at the bottom of the separator. The collected condensate is then transferred to the condensate storage vessel. Each pressure vessel has a production life that depends on the type and use of the pressure vessel itself [3]. If the operation continues beyond the proper age, it is feared that it can cause unwanted dangers. Therefore necessary a method to prevent failure of the pressure vessel [4].

RBI (risk-based inspection) is a procedure for determining when to inspect facilities based on the level of risk [5], [6]. As a result, the RBI's risk assessment is required to provide reasonably precise recommendations to avoid equipment failures. The Reserve Bank of India prioritizes and manages inspection patterns based on risk. In a system, it is common knowledge that there is a high enough risk to some of the small equipment [7], [8]. Inspection and maintenance can be improved on

Nurhadi Siswantoro is with Department of Marine Engineering, Institut Teknologi Sepuluh Nopember, Surabaya 60111, Indonesia. Email: nurhadi@ne.its.ac.id

Dwi Priyanta is with Department of Marine Engineering, Institut Teknologi Sepuluh Nopember, Surabaya 60111, Indonesia. E-mail: priyanta@its.ac.id

Jamal Ramadhan is with Department of Marine Engineering, Institut Teknologi Sepuluh Nopember, Surabaya 60111, Indonesia. Email: jamal.ramadhan116@mhs.ne.its.ac.id

Muhammad Badrus Zaman is with Department of Marine Engineering, Institut Teknologi Sepuluh Nopember, Surabaya 60111, Indonesia. E-mail: druz_zaman@ne.its.ac.id equipment that carries a high risk of failure [9-11]. RBI can determine the most optimum combination, including inspection method, scope, and frequency [7].

The RBI approach combines two parameters to determine the level of risk of the analyzed equipment: the failure probability and the failure consequences. The size of the probability of a piece of equipment failing is related to the analysis of the likelihood of failure. Meanwhile, the failure effects analysis is concerned with the effect caused by the failure event [12-15].

It is hoped that the RBI can provide a centralized damage mechanism analysis so that further consequences must be watched out for and prevented, as well as provide ideas for more effective and efficient inspections. The RBI makes it possible to revise the schedule and inspection intervals so that they are more efficient according to needs and of course this will save more costs for inspections.

\section{METHOD}

\section{A. Data Collection}

The RBI assessment was performed under normal operating conditions. The object researches are the Condensate Separator 10V2102 and Condensate Storage Vessel 10V2103. The following data must be obtained in conducting an RBI assessment:

- Type of equipment

- $\quad$ Process Flow Diagram system

- Piping and Instrumentation Diagram system

- Materials and Construction

- Previous Inspection Reports

- Composition of Fluid Contained

- Design and operation of the equipment

- Safety System

\section{B. Previous Inspection Evaluation}

Inspections that have been carried out need to be analyzed, both the results are obtained and the 
effectiveness of the inspections carried out. Inspection data is used for the analysis of the probability of failure. The inspection report data required to evaluate an inspection include:

- Schedule and frequency

- Type / method of inspection

- Inspection results

The inspection report is related to the damage factor value that will be obtained. The inspection method used will indicate the effectiveness category of the inspection. Likewise, the frequency of inspections is carried out. So that the damage factor value really depends on the results of previous inspections.

\section{Identification and determination of the damage mechanism}

Damage mechanism indicates the type of damage that most influences the success of the pressure vessel. API 581 provides 5 types of damage mechanisms that occur in pressure vessels. To determine the type of damage mechanism can be done by conducting screening criteria based on API 581. Here are 5 types of damage mechanisms that occur in pressure vessels:
a. Thinning
b. Stress Corrosion Cracking (SCC)
c. External Damage
d. High-Temperature Hydrogen Attack (HTHA)
e. Brittle Fracture

Identifying the types of damage mechanisms that exist on the pressure vessel can be done using the results of the evaluation of the existing inspection. The types of damage mechanisms chosen are the ones that have the highest risk of causing the disintegration of the equipment.

\section{Probability Analysis}

Probability of failure (PoF) analysis is analyzed by identifying the damage mechanism, assessing PoF, and identifying the causes of the risk occurring, in order to determine strategies to mitigate risks. After the damage mechanism is determined as the one that has the most influence on the failure of a pressure vessel, a probability of failure analysis will be carried out.
1) Generic Failure Frequency (gff)

The generic failure frequency value is influenced by the type of equipment being analyzed. API 581 provides recommended gff values for each type of equipment.

2) Damage Factor (DF)

The calculation of the damage factor value is determined from the damage mechanism that has been obtained. For multiple damage factors, it is necessary to calculate each influential damage factor value. After each damage factor value is obtained, then the total damage factor value can be calculated using the formula given in API 581.

3) Management System Factor (FMS)

The management system factor shows the quality of mechanical integrity and the process safety management program at a facility. For the purposes of analyzing the FMS value of 1 or the equivalent of a score of $500 \quad(50 \%$ of the maximum total score that can be obtained).

\section{E. Consequence Analysis}

Analysis of the consequences of failure $(\mathrm{CoF})$ in the $\mathrm{RBI}$ program is used to categorize equipment based on how significant the damage will be if a failure occurs. Consequence analysis is used to assist in setting priorities for the inspection program. The consequences of this study are categorized as follows:

a. Effect on safety and health

b. Effect on the environment around the equipment

According to API 581, this analysis uses level 1 to calculate the consequence of failure.

\section{F. Risk Level Determination}

The failure probability and the result of failure gained in the previous step are combined in the risk assessment. The risk formula is formulated as follows [8]:

Risk $=$ probability $\mathrm{x}$ consequence

The risk level can be determined using API 581 risk matrix. Figure 1 shows the API 581 risk matrix.

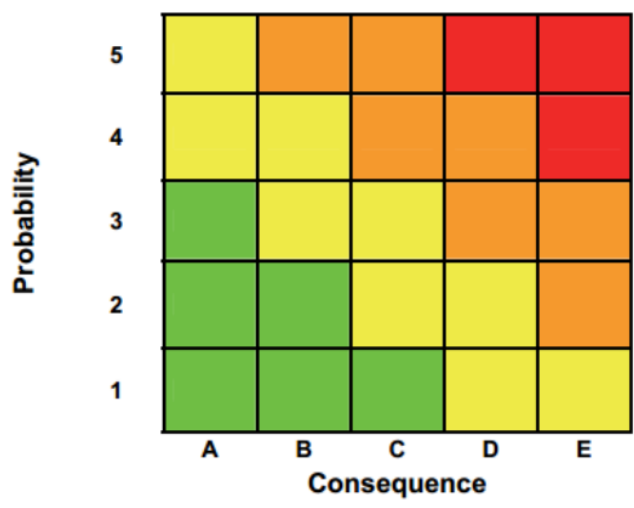

RISK

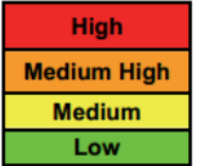

Figure. 1. API 581 risk matrix. 
TABLE 1

DATA OF CONDENSATE SEPARATOR 10V2102

\begin{tabular}{ll}
\hline \multicolumn{1}{c}{ Parameter Item } & \multicolumn{1}{c}{ Value } \\
\hline Size & $1500 \mathrm{~mm}$ (ID) x 3500 mm (T/T) \\
Year Built & 2013 \\
Design Code & ASME VIII Div.2 \\
Phase & Condensate - Liquid \\
Cladding & No \\
Coating & Painting \\
Joint Efficiency & 1 \\
Material & Carbon Steel SA516-70 \\
Design Pressure & $1500 \mathrm{kPa}$ \\
Design Temperature & $70{ }^{\circ} \mathrm{C}$ \\
Operating Pressure & $350 \mathrm{kPa}$ \\
Operating Temperature & $51{ }^{\circ} \mathrm{C}$ \\
Thickness & $19.7 \mathrm{~mm}$ \\
Min. Wall Thickness & $16.026 \mathrm{~mm}$ \\
Corrosion Allowance & $1.25 \mathrm{~mm}$ \\
\hline
\end{tabular}

TABLE 2.

DATA OF CONDENSATE STORAGE VESSEL 10V2103

\begin{tabular}{ll}
\hline \multicolumn{1}{c}{ Parameter Item } & \multicolumn{1}{c}{ Value } \\
\hline Size & $2000 \mathrm{~mm}$ (ID) x $5000 \mathrm{~mm}$ (T/T) \\
Year Built & 2013 \\
Design Code & ASME VIII Div. 2 \\
Phase & Condensate - Liquid \\
Cladding & No \\
Coating & Painting \\
Joint Efficiency & 1 \\
Material & Carbon Steel SA516-70 \\
Design Pressure & $1500 \mathrm{kPa}$ \\
Design Temperature & $70{ }^{\circ} \mathrm{C}$ \\
Operating Pressure & $5 \mathrm{kPa}$ \\
Operating Temperature & $13{ }^{\circ} \mathrm{C}$ \\
Thickness & $19.4 \mathrm{~mm}$ \\
Min. Wall Thickness & $16.332 \mathrm{~mm}$ \\
Corrosion Allowance & $1.25 \mathrm{~mm}$ \\
\end{tabular}

\section{G. Inspection Planning}

Inspection planning is developed from an analysis of several data sources. Inspections should be scheduled at intervals taking into account the following [1]:

a. Type of damage

b. Corrosion rate

c. The failure detection capability of the checking technique used

d. Frequency of inspections carried out

\section{RESULT AND DISCUSSION}

\section{A. Condensate System}

Condensate is a type of liquid hydrocarbon produced by gas or oil wells. Condensate wells produce raw natural gas and also heavy hydrocarbons, which are low molecular compounds, whereas gas well produces only raw natural gas. Natural gas condensate, also known as natural gasoline or simply condensate, refers to gases that are liquid at a certain temperature, such as pentane and heavier compounds [16].

Liquid condensate is separated from the gas through a device called a separator. The form is a pressure vessel and the condensate is passed into it. The function of the condensate separator is as a separator between gas and condensate fluid, while the function of the condensate storage vessel is to accommodate condensate from the separation of the separator. In this research, the two types of equipment were analyzed by RBI to determine the schedule and program of inspection.

\section{B. Pressure Vessel Data}

Complete data from the analyzed equipment is needed in calculating the RBI. These data include vessel design 
and construction, vessel operational data, gas fluid data stored in the vessel, inspection data, and other data that support research. The data will be processed to calculate PoF dan CoF. Table 1 shows the data from the $10 \mathrm{~V} 2102$ condensate separator and Table 2 shows the data from the 10V21023 condensate storage vessel.

\section{Fluid Composition Data}

The fluid content that is processed in the production gas separator system can be seen by looking at the company data in the heat material balance (HMB) file.
As we know that Heat Material Balance (HMB) is one of the basic process engineering documents produced by a process engineer when designing the initial process plant. Table 3 and 4 show the chemical composition of the separator and storage vessel.

TABLE 3.

DATA OF CONDENSATE SEPARATOR 10V2102

\begin{tabular}{cc}
\hline Composition & Amount (\% mole) \\
\hline $\mathrm{H}_{2} \mathrm{~S}$ & 0.000051 \\
$\mathrm{CO}_{2}$ & 0.983734 \\
$\mathrm{H}_{2} \mathrm{O}$ & 0.000058 \\
Methane & 0.000001 \\
Ethane & 0.000001 \\
Propane & 0.004003 \\
i-Butane & 0.004003 \\
n-Butane & 0.004003 \\
i-Pentane & 0.00216 \\
n-Pentane & 0.001982 \\
n-Hexane &
\end{tabular}

TABLE 4.

Data of Condensate Storage Vessel 10V2102

\begin{tabular}{cc}
\hline Composition & Amount (\% mole) \\
\hline $\mathrm{H}_{2} \mathrm{~S}$ & 0.001116 \\
$\mathrm{CO}_{2}$ & 0.001569 \\
$\mathrm{H}_{2} \mathrm{O}$ & 0.002643 \\
Methane & 0.000056 \\
Ethane & 0.000089 \\
Propane & 0.245081 \\
i-Butane & 0.245856 \\
n-Butane & 0.247182 \\
i-Pentane & 0.133505 \\
n-Pentane & 0.122778 \\
n-Hexane & \\
\hline
\end{tabular}

\section{Damage Mechanism Determination and Identification}

Damage mechanism is the cause of damage or disintegration of equipment. API RP 581 provides 21 types of damage mechanisms, selecting the type of damage mechanism is carried out by screening the composition of the pressure vessel material, the fluid that is processed/stored in the pressure vessel, the processing environment around the pressure vessel, and other conditions that also affect the screening of the damage criteria. the mechanism as in API 581 Part 2.

The type of damage mechanism chosen is the cause of the highest damage that most affects the performance of the pressure vessel. The pressure vessel being analyzed is structured of carbon steel material (SA516 grade 70).
The fluid stored is liquid condensate, which does not contain sulfuric acid and other harmful compounds. Coating protection in the form of painting in good condition. Operating temperatures are at $51^{\circ} \mathrm{C}$ and $13^{\circ}$ $\mathrm{C}$ and are at an operating pressure of $350 \mathrm{Kpa}$ and $5 \mathrm{Kpa}$. Judging from the conditions above, the most suitable type of damage mechanism is thinning. However, when viewed from the external condition of the surrounding location which is in the sea area with high enough rainfall, the external damage mechanism also affects the condition of the pressure vessel. So that the type of damage mechanism is multiple damage mechanism between thinning and external. 


\section{E. Probability of Failure $(\mathrm{PoF})$}

The PoF is defined as probability of failure in a certain period. PoF is analyzed by identifying the damage mechanism and identifying the causes for the risk to occur, in order to determine strategies to mitigate risks.

The following equation is used to compute the likelihood of failure 1:

$$
P o F=\operatorname{gff} x F M S x D f
$$

Which are :

PoF : Probability of failure

gff : generic failure frequency

$\mathrm{F}_{\mathrm{MS}}$ : management systems factor

DF : damage factor

1) Determine the general failure frequency ( $g f f)$

The frequency of failure of any piece of equipment is represented by the value of gff. The generic failure frequency value is influenced by the type of equipment being analyzed. API 581 provides recommended gff values for each type of equipment. The equipment being analyzed by RBI is a DRUM type, so according to the table, it has a total gff value of $3.06 \mathrm{E}-5$ (according to API 581).

2) Determining the management factor (FMS) Value

For the purposes of analyzing the FMS value of 1 or the equivalent of a score of 500 (50\% of the maximum total score that can be obtained).

3) Determine the value of damage factor

The morphology of equipment failure is influenced by the damage factor. The damage factor results are thinning damage factor and external damage factor, according to damage procedures scanners (multiple damage factor).

\section{a. Determine the Thinning Damage Factor}

All equipment needs to be evaluated for indicators of thinning or depletion damage. Thinning is caused by various mechanisms such as corrosion and erosion factors. Corrosion factors are caused by compounds contained in process fluids such as $\mathrm{CO}_{2}, \mathrm{H}_{2} \mathrm{~S}, \mathrm{H}_{2} \mathrm{O}, \mathrm{Cl}_{2}$, and amines. The erosion factor is caused by a combination of fluid flow velocity and particle size in the fluid.

For thinning calculations on the 10V2102 Condensate Storage Vessel, based on the results of the screening criteria in API RP 581 Part 2 Annex 2.A, the biggest corrosion factor which has the most influence is $\mathrm{CO} 2$ corrosion. $\mathrm{CO} 2$ corrosion caused by the presence of $\mathrm{CO} 2$ and water in the process fluid and construction material is SA-516 GR.70N which is carbon steel with $\mathrm{Cr}$ levels $<13 \%$.

Based on API RP 581, there are 2 types of thinning, namely general and localized. The calculation results for the thinning damage factor on Condensate Separator $10 \mathrm{~V} 2102$ are 0.456834 on the RBI date and 1.51156 on the RBI plan date. Whereas for Condensate Storage
Vessel 10V2103 it is 0.426637 on the RBI date and 0.526190 on the RBI plan date.

\section{b. Determine the External Damage Factor}

For external corrosion calculations, based on the results of screening criteria in API RP 581, the biggest factor that has the most influence on external corrosion is caused by the operating temperature of $510 \mathrm{C}$ and $13 \mathrm{oC}$ and the location of the plant which is near the sea with high rainfall. External corrosion mitigation is carried out through proper painting. A routine inspection program for damage and paint repainting will prevent this mostly external corrosion.

The calculation results for external corrosion damage factors on Condensate Separator 10V2102 are 0.357265 on the RBI date and 0.398749 on the RBI plan date. Meanwhile, for Condensate Storage Vessel 10V2103 it is 0.404032 on the RBI date and 0.460283 on the RBI plan date.

\section{c. Determine the Total Damage Factor Value}

The damage factor is computed using the most influential type of damage mechanism. If there are more than one damage mechanism, the damage factor is computed using the damage factor formula for multiple damage mechanisms, which is shown below:

$$
\begin{aligned}
& D_{f-t o t a l}=\max \left[D_{f-g o v}^{\text {thin }}, D_{f-g o v}^{\text {extd }}\right]+D_{f-g o v}^{S S C}+D_{f-g o v}^{\text {htha }} \\
& +D_{f-g o v}^{b r i t}+D_{f-g o v}^{m f a t}
\end{aligned}
$$

So that the calculation results for the total damage factor on Condensate Separator 10V2102 are 0.456834 on the RBI date and 1.511566 on the RBI plan date. Meanwhile, the 10V2103 Condensate Storage Vessel is 0.426637 on the RBI date and 0.526190 on the RBI plan date.

The calculation of the damage factor on the pressure vessel is influenced by the category of the effectiveness of the inspection that has been carried out. The inspection that has been carried out is one time using the visual examination method with thickness measurements. The category of inspection effectiveness determines the parameters of the damage factor. So that the amount of damage factor can be determined based on table 5.1 API 581.

A detailed summary of the probability calculation for the condensate separator and condensate storage vessel can be seen in table 5, showing the final result of the PoF calculation.

\section{F. Consequence of Failure}

A consequence of Failure $(\mathrm{CoF})$ is defined as if the equipment fails, this is the impact that will arise. Failure's impacts can be quantified as well as qualitatively proved. In the RBI program, the $\mathrm{CoF}$ analysis is used to classify equipment based on how much harm it can cause if it fails.

In this discussion, the consequence value to be discussed is the consequence of the area or area of impact. 
TABLE 5 .

PROBABILITY OF FAILURE RESULT

\begin{tabular}{cccc}
\multicolumn{4}{c}{ PROBABILITY OF FAILURE RESULT } \\
\hline No. & Equipment & RBI date & Plan date \\
\hline 1. & $10 \mathrm{~V} 2102$ & $1.40 \mathrm{E}-05$ & $4.63 \mathrm{E}-05$ \\
2. & $10 \mathrm{~V} 2103$ & $1.31 \mathrm{E}-05$ & $1.61 \mathrm{E}-05$ \\
\hline
\end{tabular}

$C A=\max \left[C A_{c+n d}, C A_{i+1 j}\right]$

\section{G. Consequence of Failure}

The impact that would arise if the equipment fails is known as a consequence of failure (CoF). The consequences of failure can be demonstrated both quantitatively and qualitatively. CoF analysis in the RBI program is used to categorize equipment based on how significant the damage will be if a failure occurs.

In this discussion, the consequence value to be discussed is the consequence of the area or area of impact. The output of this consequence calculation will be in the form of how wide the area of the fire is affected when the leak occurs with a certain hole diameter scenario in accordance with the value specified by API RP 581. API RP 581 provides a choice of several scenarios of leak holes, namely 0.25 inch, 1 inch, 4 inches, and 16 inches. The scenario of the hole on the Pressure Vessel by using a 0.25 -inch hole is the smallest leakage hole scenario.

The calculation of the area of consequences is done using a spreadsheet. The calculation of the consequences is carried out with the following steps:

1) Identify the representative fluids as well as their associated properties.

2) Selecting the Size of the Release Hole

3) Calculation of the Release Rate

4) Calculate the amount of fluid inventory that can be released.

5) Decide on the kind of release (Continuous or Instantaneous)

6) Calculate the detection impact and isolation systems on the magnitude of the release

7) Calculate the Release Rate and Mass for the Analysis of Consequences

8) Determine the Risks of Flammable and Explosive Materials

9) Define the final regions of probability consequence.

The consequence of failure area calculated using equations:
Which are:

$C A_{\text {ctnd }}=$ component damage consequence area $\left(\mathrm{m}^{2}\right)$

$C A_{i+1 j}=$ personel injury consequence area $\left(\mathrm{m}^{2}\right)$

Component damage consequence area magnitude counted with 3 equations below :

$$
C A_{c+\pi d}=\max \left[C A_{c+\pi d}^{f[a+\pi}, C A_{c+\pi d}^{\mathrm{tax}}, C A_{c+\pi d}^{\mathrm{n} f \mathrm{ft} t}\right]
$$

Dimana :

$$
\begin{aligned}
& C A_{c+\pi d}^{f[a+\pi}=\text { flammable/explosion consequence area }\left(\mathrm{m}^{2}\right) \\
& C A_{c+\pi d}^{+a x d}=\text { toxic consequence area }\left(\mathrm{m}^{2}\right) \\
& C A_{c+\pi d}^{+1 f+\pi t}=\text { non-toxic non-flam consequence area }\left(\mathrm{m}^{2}\right)
\end{aligned}
$$

Meanwhile, personnel injury consequence area counted with 4 equations below :

$$
C A_{i+1 j}=\max \left[C A_{i+1 j}^{f[a+n}, C A_{i+1 j}^{\operatorname{tax}}, C A_{i+1 j}^{\mathrm{n} f \mathrm{trt}}\right]
$$

Which are :

$$
\begin{aligned}
& C A_{i+j j}^{f[a+m}=\text { flammable/explosion consequence area }\left(\mathrm{m}^{2}\right) \\
& C A_{i+j j}^{\mathrm{tax} j}=\text { toxic consequence area }\left(\mathrm{m}^{2}\right) \\
& C A_{i+1 j}^{\mathrm{n} f \mathrm{t+1}}=\text { non-toxic non-flam consequence area }\left(\mathrm{m}^{2}\right)
\end{aligned}
$$

API 581 defines two types of consequences: component damage area consequences and personnel injury consequences. The mass of the fluid and the size of the escape hole have a big impact on the area's consequences. Consequence analysis was carried out for each escape hole size.

The summary of the area consequence calculation for a pressure vessel can be observed in table 6 which shows the final result of the area consequence on the pressure vessel carried out by the research.

TABLE 6.

A CONSEQUENCE OF FAILURE RESULT

\begin{tabular}{ccc} 
& \multicolumn{2}{c}{ A CONSEQUENCE OF FAILURE RESULT } \\
\hline No. & Equipment & Consequence $\left(\mathrm{m}^{2}\right)$ \\
\hline 1. & $10 \mathrm{~V} 2102$ & 144.032 \\
2. & $10 \mathrm{v} 2103$ & 443.843 \\
\hline
\end{tabular}

\section{H. Risk Level Determination}

The summary of the area consequence calculation for a pressure vessel can be observed in table 6 which shows the final result of the area consequence on the pressure vessel carried out by the research.
The risk is calculated on the condition of the RBI date and Plan date. The level of risk on the pressure vessel can be determined by comparing the risk calculation results on the RBI date and Plan date with the total of the risk target. Table 7 shows the total risk for each pressure vessel. 
International Journal of Marine Engineering Innovation and Research, Vol. 6(1), Mar. 2021. 1-10 (pISSN: 2541-5972, eISSN: 2548-1479)

TABLE 7.

RISK ON EACH PRESSURE VESSEL

\begin{tabular}{lccc}
\hline No. & Equipment & On RBI date & On Plan date \\
\hline 1. & $10 \mathrm{~V} 2102$ & $2.02 \mathrm{E}-03$ & $6.67 \mathrm{E}-03$ \\
2. & $10 \mathrm{~V} 2103$ & $5.81 \mathrm{E}-03$ & $7.15 \mathrm{E}-03$ \\
\hline
\end{tabular}

TABLE 8.

RISK CATEGORY ON RBI 581 [8]

\begin{tabular}{|c|c|c|c|c|}
\hline \multicolumn{3}{|c|}{ Probability Category (1) } & \multicolumn{2}{c|}{ Consequence Category (2) } \\
\hline Category & Range & Damage F. Range & Category & ${\text { Range }\left(\boldsymbol{m}^{2}\right)}^{2}$ \\
\hline 1 & $P f \leq 3.06 E-05$ & Df-total $\leq 1$ & $A$ & $C A \leq 9.29$ \\
\hline 2 & $3.06 E-05<P f \leq 3.06 E-04$ & $1<D f$-total $\leq 10$ & $B$ & $9.29<C A \leq 92.9$ \\
\hline 3 & $3.06 E-04<P f \leq 3.06 E-03$ & $10<D f$-total $\leq 100$ & $C$ & $92.9<C A \leq 929$ \\
\hline 4 & $3.06 E-03<P f \leq 3.06 E-02$ & $100<D f$-total $\leq 1000$ & $D$ & $929<C A \leq 9290$ \\
\hline 5 & $P f>3.06 E-02$ & $D f-$ total $>1$ & $E$ & $C A>9290$ \\
\hline
\end{tabular}

The risk determination for the piping system is sufficiently limited to the risk matrix. It is a combination of probability categories and consequence categories. The following table 8 shows the categories of failure probability and failure consequences.
The risk level on the 10V2102 condensate separator and 10V2103 condensate storage vessel can be seen in Figures 2-3 and table 9.
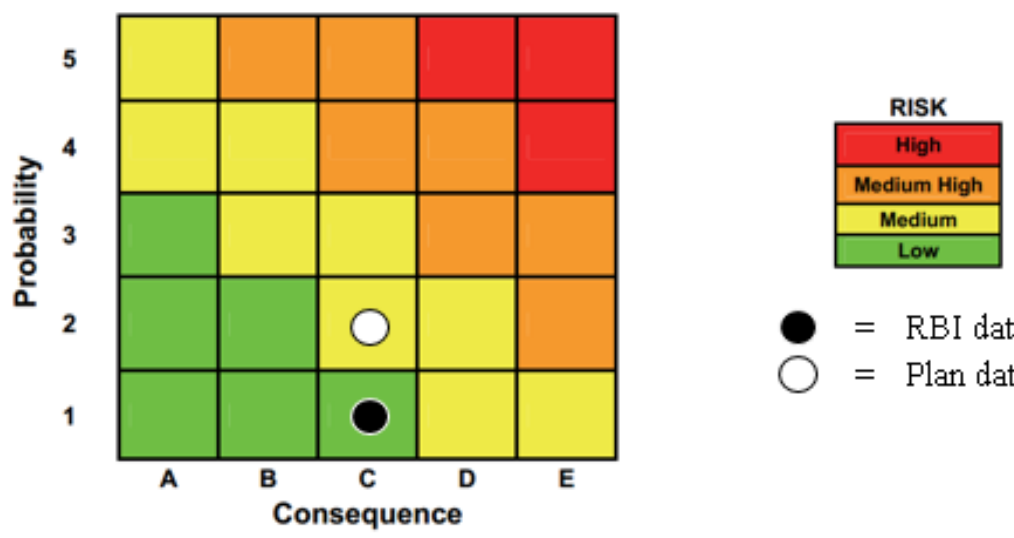

$=$ RBI date

$\bigcirc=$ Plan date

Figure. 2. Risk level on condensate separator 10V2102.
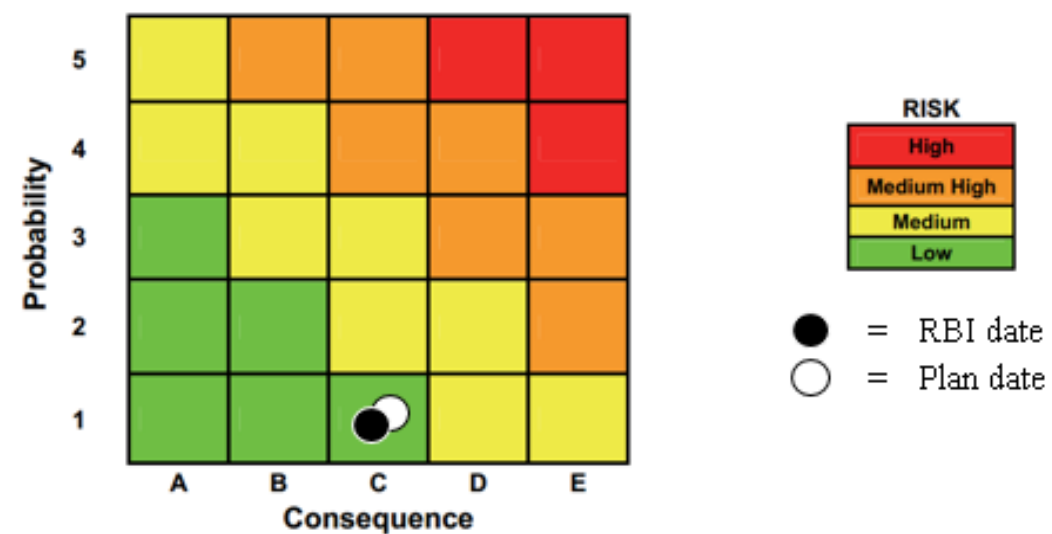

Figure. 3. Risk level on condensate storage vessel 10V2103. 
TABLE 9.

RISK CATEGORY ON PRESSURE VESSEL

\begin{tabular}{|c|c|c|c|c|c|}
\hline \multirow{2}{*}{ Pressure Vessel } & \multicolumn{2}{|c|}{ Probability category } & \multirow{2}{*}{$\begin{array}{c}\text { Cons. } \\
\text { Category }\end{array}$} & \multicolumn{2}{|c|}{ Risk Level (Risk Matrix) } \\
\hline & RBI date & Plan date & & RBI date & Plan date \\
\hline $\begin{array}{l}\text { Condensate } \\
\text { Separator }\end{array}$ & 1 & 2 & $\mathrm{C}$ & $1 \mathrm{C}$ & $2 \mathrm{C}$ \\
\hline $\begin{array}{c}\text { Condensate Storage } \\
\text { Vessel }\end{array}$ & 1 & 1 & $\mathrm{C}$ & $1 \mathrm{C}$ & $1 \mathrm{C}$ \\
\hline
\end{tabular}

I. $\quad$ Target Inspection Date

The intersection of the risk curve on the RBI date with the target risk curve yields the inspection date's target. On the 10V2102 condensate separator, Figure 4 gives a comparison of the RBI date and the target date.
Meanwhile, on the condensate storage vessel $10 \mathrm{~V} 2103$, figure 5 illustrates a comparison of the RBI date and the target date.

\section{RBI date VS Plan date}

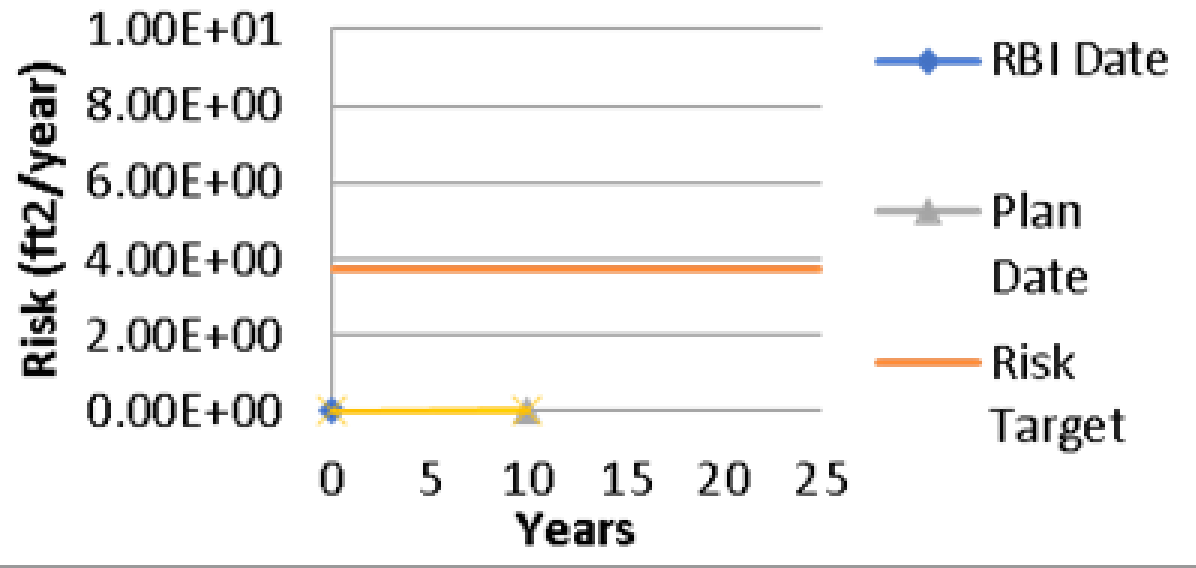

Figure. 4. Curve Graphic RBI date and Plan date on Condensate Separator 10V2102.

\section{RBI date VS Plan date}

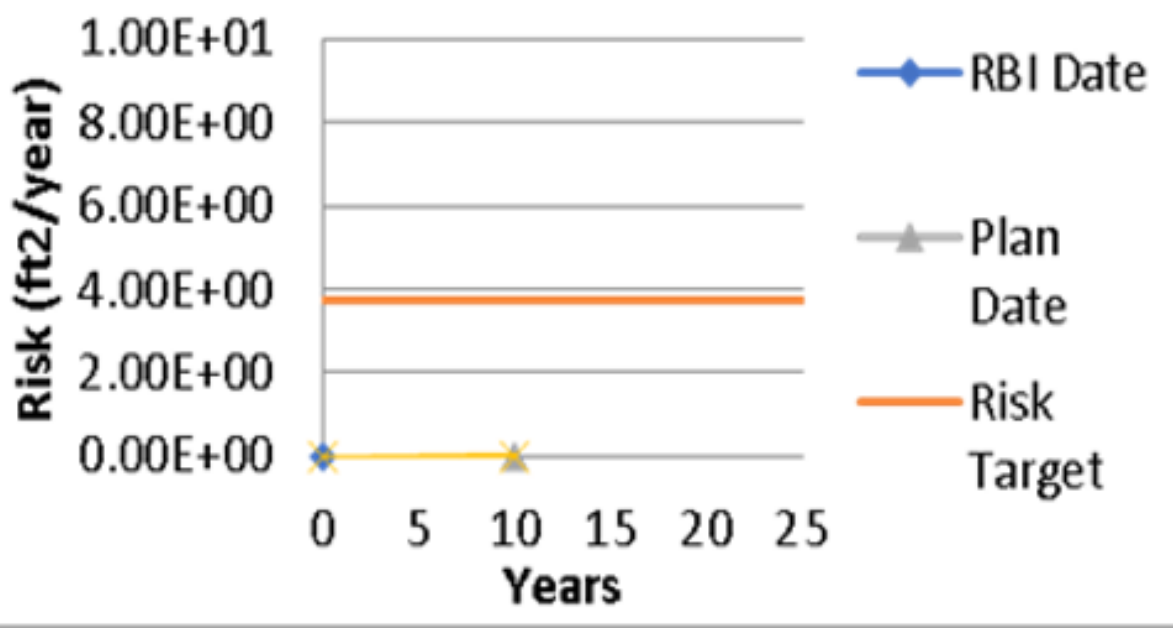

Figure. 5. Curve Graphic RBI date and Plan date on Condensate Storage Vessel 10V2103. 
To ensure equipment integrity, all types of pressure vessels must be inspected at the interval provided according to risk-based inspection results, recommended standards, or government regulations.

The results of the inspection interval surpass the standard's recommendations based on the findings of the inspection date computation. Therefore, to determine the inspection date following the standard recommendation API RP 510 has provided recommendations for the maximum inspection interval for pressure vessels. According to API RP 510, the maximum interval to perform the external inspection is 5 years. Meanwhile, for an internal inspection maximum is 10 years. So the inspection date of Condensate Separator 10V2102 is 2 April 2026 and 11 February 2027 for Condensate Storage Vessel 10V2103.

\section{J. Inspection Planning}

Inspection is an evaluation of the quality of several characteristics related to standards or specifications. Inspection consists of several activities comparing with specifications, assessing suitability, classifying according to cases, classifying not according to cases, and recording and reporting of data obtained. An inspection plan is developed and implemented for the RBI object equipment. The object of the RBI referred to in this study is the Pressure Vessel [5].

Each RBI object has different guidelines and standards in preparing an inspection plan. For pressure vessels, the inspection plan is prepared based on API 572. However, there are also inspection plans that are common among the equipment described in API RP 581 part 2 Annex $2 \mathrm{C}$, including thinning, corrosion under insulation (CUI), and stress corrosion cracking (SCC).

Specific types of corrosion are detected and measured using inspection plans. Each type of damage has its own method for detecting and measuring it. API RP 581 recommends a number of inspection procedures, including:

The recommended method for identifying damage to pressure vessels is based on the type of damage mechanism that occurs, as follows:

1. Visual Testing (VT) Inspection

2. Ultrasonic Test (UT) Inspection

3. Radiography Test (RT) Inspection

4. Eddy Current Test

5. Guided Wave Examination (GWT)

6. Magnetic Particle Inspection

TABLE12.

INSPECTION PLAN ON PRESSURE VESSEL BASED ON API 581 [8]

\begin{tabular}{|c|c|c|c|c|}
\hline No & $\begin{array}{c}\text { Damage Factor } \\
\text { Type }\end{array}$ & $\begin{array}{c}\text { Inspection Effectiveness } \\
\text { Category }\end{array}$ & Intrusive Inspection Example & Non-Intrusive Inspection Example \\
\hline 1 & Local thinning & $\begin{array}{l}\mathrm{C} \\
\text { (fairly effective) }\end{array}$ & $\begin{array}{l}\text { For the total surface area: } \\
>5 \% \text { visual examination } \\
\text { AND } \\
>5 \% \text { of the spot ultrasonic thickness } \\
\text { measurements }\end{array}$ & $\begin{array}{l}\text { For the total surface area: } \\
>50 \% \text { spot UT or random UT scans } \\
\text { (automated or manual) } \\
\text { OR } \\
\text { Random profile radiography of the selected } \\
\text { area }\end{array}$ \\
\hline 2 & $\begin{array}{l}\text { External } \\
\text { Corrosion }\end{array}$ & $\begin{array}{l}\text { C } \\
\text { (fairly effective) }\end{array}$ & \multicolumn{2}{|c|}{$\begin{array}{l}\text { Visual inspection of more than } 30 \% \text { of the exposed surface area, with UT, RT, or pit } \\
\text { gauge follow-up as needed }\end{array}$} \\
\hline
\end{tabular}

\section{CONCLUSION}

The risk category of the current RBI date is low risk for the condensate separator 10V2102 and condensate storage vessel $10 \mathrm{~V} 2103$. The results of the inspection interval surpass the standard's recommendations based on the findings of the inspection date computation. Therefore, according to API RP 510, the maximum interval to perform the external inspection is 5 years. Meanwhile, for an internal inspection maximum is 10 years. So the inspection date of Condensate Separator 10V2102 is 2 April 2026 and 11 February 2027 for Condensate Storage Vessel 10V2103. The inspection methods chosen were Visual Testing, Ultrasonic Testing (UT), Radiography Test (RT), Eddy Current Test, and Magnetic Particle Inspection.

\section{REFERENCES}

[1] American Petroleum Institute (API), "Pressure Vessel Inspection Codes API 510 Ninth Edition," Washington, D.C, API Publishing Services, 2014.

[2] N Cahyono, MB Zaman, N Siswantoro, D Priyanta, T Pitana, "Risk Analysis Using the Risk-Based Inspection (RBI) Method for a Pressure Vessel at Offshore Platform," IOP Conf. Ser.: Mater. Sci. Eng. 1052 012051, 2021.
[3] Siswantoro, N., D Priyanta, MB Zaman, PS Andaka, W Busse, "Risk analysis of scrubber vessel using risk-based inspection method in geothermal power plant," IOP Conf. Ser.: Earth Environ. Sci. 649 012016, 2021.

[4] Yang, X.; Haugen, S.; Paltrinieri, N. "Clarifying the concept of operational risk assessment in the oil and gas industry," Saf. Sci., 108, pp. 259-268, 2018.

[5] D Priyanta, M B Zaman and Semin, "The development of a risk based maintenance flowchart to select the correct methodology to develop maintenance strategies of oil and gas equipment," IOP Conf. Ser.: Mater. Sci. Eng. 1052 012042, 2021

[6] Siswantoro, N., Semin, S., Zaman, M., "Criticality Assessment for Marine Diesel Engine Using Failure Mode and Effect Criticality Analysis (FMECA) Approach: Case Study on Lubricating Oil System," International Review of Mechanical Engineering (IREME), 14 (4), pp. 258-263, 2020.

[7] American Petroleum Institute (API), "Risk based Inspection Codes API 580 Ninth Edition,” Washington, D.C, API Publishing Services, 2016.

[8] American Petroleum Institute (API)," Risk based Inspection Technology Codes API 581 Ninth Edition," Washington, D.C, API Publishing Services, 2016.

[9] Rachman, A.; Ratnayake, R.C., "Machine learning approach for risk-based inspection screening assessment," Reliab. Eng. Syst. Saf., 185, pp.518-532, 2019.

[10] Meng, X.K.; Chen, G.M.; Zhu, G.G.; Zhu, Y., "Dynamic quantitative risk assessment of accidents induced by leakage on offshore platforms using DEMATEL-BN," Int. J. Nav. Archit. Ocean Eng., 11(1), pp.22-32, 2018. 
[11] Singh, K.; Maiti, J., “A novel data mining approach for analysis of accident paths and performance assessment of risk control systems," Reliab. Eng. Syst. Saf., 202, 107041, 2020.

[12] Wu, S.M.; Zhang, L.B.; Fan, J.C.; Zhou, Y.F., "Dynamic risk analysis of hydrogen sulfide leakage for offshore natural gas wells in MPD phases," Proc. Saf. Environ. Protect, 122, pp. 339351.2019 .

[13] Syed, Z.; Lawryshyn, Y., "Risk analysis of an underground gas storage facility using a physics-based $\mathrm{T}$ system performance model and Monte Carlo simulation,” Reliab. Eng. Syst. Saf., 199, 106792,2020
[14] Chen, C.; Reniers, G., "Khakzad, N. A thorough classification and discussion of approaches for modeling and managing domino effects in the process industries," Saf. Sci., 125, 104618, 2020

[15] R. Islam, F. Khan, R. Abbassi and V. Garaniya, "Human Error Probability Assessment During Maintenance Activities of Marine Systems," Safety and Health at Work, Vol. 9, n. 1, pp. 42-52, 2018.

[16] Salmani N., Fatehi R., Azin R., "On the Liquid Condensate Vertical Migration Near the Production Well of Gas-Condensate Reservoirs", 2019. 